\title{
Data from diversity of Zygoptera (Odonata) in the state of Amapá, Brazil
}

Manoel Daltro Nunes Garcia-Junior, Monique Telcia dos Santos Damasceno, Tiago Silva da Costa \& Raimundo Nonato Picanço Souto

Laboratory Arthropoda. Department of Biological and Health Sciences, University Federal of Amapá, Amapá, Brazil.

Correspondence

M.D.N. Garcia-Junior

E-mail: m.d.juniorbio@gmail.com

Received: 6 November 2020

Accepted: 21 April 2021

Published on-line: 28 June 2021

\section{Resumen}

Datos del diversidad de los Zygoptera (Odonata) en el estado del Amapá, Brasil

El Amapá está ubicado en el norte de Brasil, numerosos grupos están poco estudiados en el estado, entre ellos el orden Odonata. El objetivo del presente trabajo es presentar datos sobre la diversidad de los Zygopteros de Amapá. El muestreo se realizó entre los años 2018 y 2019 . Fueron capturados 602 individuos, de los cuales, 26 especies son nuevos registros para el estado. Para el Amapá se registraron 58 especies de Zygoptera, insertadas en 27 géneros y siete familias. Coenagrionidae, con 45 especies registradas, comprendió la mayor abundancia durante el estudio con aproximadamente el $81 \%$ de los organismos capturados. El presente trabajo incrementa en $44 \%$ el número de especies de Zygoptera para el estado, los resultados encontrados adquieren alta relevancia en el reconocimiento de la diversidad del orden Odonata en Amapá y el bioma amazónico.

Palabras clave: Amazonas; Insectos; Ecología; Diversidad.

\section{Abstract}

The Amapá is located in northern Brazil, numerous groups are little studied in the state, among them the order Odonata. The objective of the present work is to present data on the diversity of Amapá Damselflies. Sampling was carried out between the years 2018 and 2019. Were captured 602 individuals, of which, 26 species are new records for the state. The Amapá has so far registered 58 species of Zygoptera, inserted in 27 genera and seven families. Coenagrionidae, with 45 species registered comprised the highest abundance during the study with approximately $81 \%$ of the captured organisms. The present work increases the number of species of zygopterans by $44 \%$ for the state, thus, the results found acquire high relevance in the recognition of the diversity of the order Odonata in Amapá and the Amazon biome.

Key words: Amazon; Insects; Ecology; Diversity. 


\section{Introduction}

Dragonflies and damselflies are insects belonging to the order Odonata, they are amphibiotic, hemimetabolic organisms with predatory habits, both in their larval and adult stages (Corbet 1980). Worldwide, the order comprises about 7,000 species (Kalkman et al. 2008), dragonflies are present on almost all continents, with the exception of Antarctica (Trueman 2007). In the neotropical region, the number of species is close to 1,800 (Von Ellenrieder 2009), and in Brazil about 860 species are registered (Pinto 2018).

The order Odonata is divided into two suborders: Anisoptera and Zygoptera (Dijkstra et al. 2013). Individuals of the suborder Zygoptera have petiolate wings bases, and with similar shape to each other. When resting, the damselflies normally have their wings closed vertically to the body axis (Costa et al. 2012). Another characteristic of the suborder is its generally limited flight capacity, which can present erratic and commonly short-term displacement (Corbet 1999).

According to Clausnitzer et al. (2009), one in ten Odonata species is at risk of disappearing. In the Red Book of Threatened Brazilian Fauna, of the 15 species of the order Odonata in some degree of danger, 11 are Zygoptera (De Marco et al. 2018). Damselflies species are strongly affected because of their ecophysiological conditions (Corbet 1999), due to the decrease in environmental integrity (Pinto et al. 2012, Carvalho et al. 2013, Monteiro-Junior et al. 2013, 2014, Brasil et al. 2014), and the dispersion capacity of adults (McPeek 1989).

In the northern region, Amapá, even with a large area intended for preservation, presents a high lack of studies for several groups, including the Odonata order. Among the few works carried out with the order in the state, are the descriptions of the new species made by Santos \& Machado (1961); Machado (2009) and the surveys of species by Silveira (2003) and Garcia-Junior et al. (2020). In the study of Garcia-Junior et al. (2020) carried out in a small area of the state, 53 species of Odonata were registered, of which 27 corresponded to new records for the Amapá. With that, the objective of the present work is to present a list of Zygoptera for the state, adding new records to the fauna.

\section{Materials and methods}

\section{Study area}

The state of Amapá is located in the northern region of Brazil, inserted in the Amazon biome in an area known as the Guiana Shield (Fig. 1), the state's territory comprises about $70 \%$ of its area of environments protected by law (Oliveira 2010). The climatic classification of Amapá according to Köppen is Am (Tropical monsoon climate) type, with an average annual temperature of $27^{\circ} \mathrm{C}$, and an average rainfall of $3330 \mathrm{~mm}$.

\section{Data collect}

The list of Zygoptera for Amapá includes a literature review, along with the collection of individuals in five counties in the state: Laranjal do Jari, Macapá, Mazagão Velho, Oiapoque and Porto Grande (Fig. 1), the samplings were performed between the years 2018 and 2019, under the SISBio Collection License No. 52371-1. The specimens of damselflies were captured with the help of an entomological dip net between 9:00 am and 4:00 pm, time of the peak of these insects' activities. The collected organisms were treated according to the methodology proposed by Lencioni (2006). For the identification, the taxonomic keys of Lencioni (2005, 2006, 2017), Heckman (2006) and Garrison et al. (2010) were used. The collected specimens were deposited in the ArthroLab entomological collection at the Federal University of Amapá-UNIFAP.

\section{Statistical analysis}

To measure the sampling effort and number of species collected, the non-parametric Jackknife1 estimator was used, and the rarefaction curve was generated from the estimator. Jackknife 1 and the rarefaction curve were calculated using software $\mathrm{R}$ (R Core Team 2019) using the vegan package (Oksanen et al. 2019).

\section{Results}

During the study, 602 individuals were captured, of which, among the identified species, 26 comprise new records for the state. As of the new occurrences, Amapá has so far had 58 species of $\mathrm{Zy}-$ goptera, inserted in 27 genera and seven families (Table 1). 


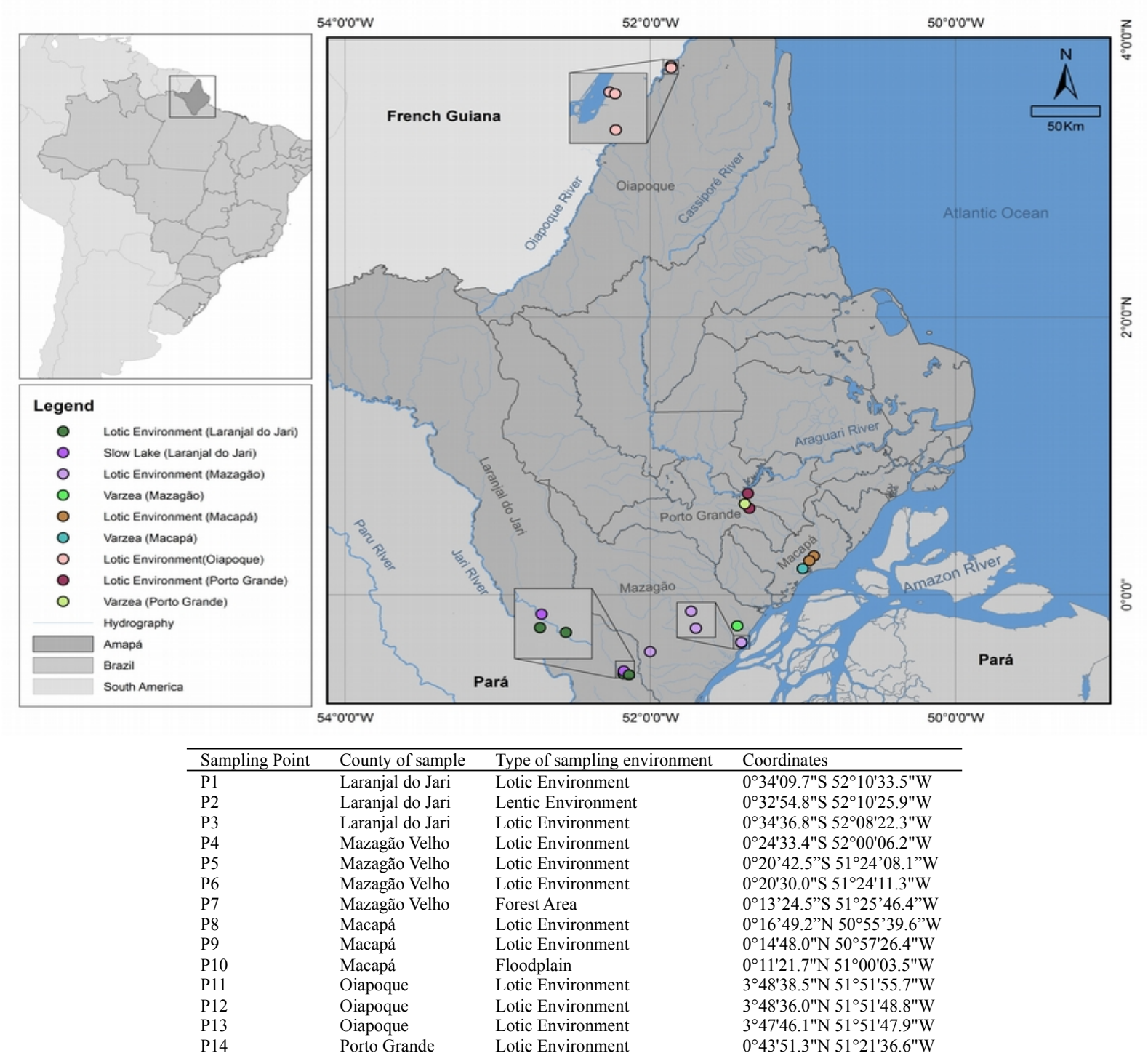

Figura 1. Mapa con la ubicación de los condados de Laranjal do Jari, Macapá, Mazagão Velho, Oiapoque e Porto Grande (AP) Brasil donde se realizaron las colecciones de Zygoptera.

Figure 1. Map with the sampling points of the counties of Laranjal do Jari, Macapá, Mazagão Velho, Oiapoque and Porto Grande (AP) Brazil where the Zygoptera collections were carried out.

With 510 specimens collected, Coenagrionidae corresponded to the family with the highest abundance, representing approximately $81 \%$ of the captured organisms. With just over 10\%, Calopterygidae $(n=63)$ was the second most representative family during the study, Dicteriadidae and Perilestidae with only one and two specimens, respectively, were the families with the lowest number of sampled organisms.

The genus Acanthagrion Selys, 1876 was the most diverse with eight species, in addition to having the largest number of organisms collected $(\mathrm{n}=123)$; Argia Rambur, $1842(\mathrm{n}=6)$ followed by Hetaerina Hagen in Selys, $1853(\mathrm{n}=5)$ and
Neoneura Selys, $1860(n=5)$ were the other genera with the greatest diversity of captured species. The most abundant species were Aeolagrion dorsale (Burmeister, 1839) $(\mathrm{n}=95)$, Acanthagrion kennedii Williamson, $1916(\mathrm{n}=85)$ and Phasmoneura exigua (Selys, 1886) $(\mathrm{n}=40)$, which together these represented about $36 \%$ of all organisms collected.

The rarefaction curve, based on the analysis of the data sampled during the study, showed good results for the sampling efforts, the collection efficiency was close to $71 \%$. The Jackknife 1 estimator demonstrated that the richness of species found corresponded to $66.1( \pm 2.94)$ (Fig. 2). 


\begin{tabular}{|c|c|c|}
\hline Family/species & Sampling points & Bibliographic Records \\
\hline \multicolumn{3}{|l|}{ Calopterygidae } \\
\hline Hetaerina amazonica Sjöstedt, 1918 & P4, P14, P15 & Garcia-Junior et al. 2020 \\
\hline Hetaerina indeprensa Garrison, $1990^{*}$ & P1, P11 & \\
\hline Hetaerina laesa Hagen em Selys, $1853^{*}$ & $\mathrm{P} 1, \mathrm{P} 3, \mathrm{P} 4, \mathrm{P} 11$ & \\
\hline Hetaerina moribunda Hagen in Selys, 1853 & P1 & Garcia-Junior et al. 2020 \\
\hline Hetaerina mortua Hagen in Selys, 1853 & P4 & Garcia-Junior et al. 2020 \\
\hline \multicolumn{3}{|l|}{ Coenagrionidae } \\
\hline Acanthagrion abunae Leonard, $1977^{*}$ & P8 & \\
\hline Acanthagrion ascendens Calvert, 1909* & P2 & \\
\hline Acanthagrion adustum Williamson, $1916^{*}$ & P4 & \\
\hline Acanthagrion amazonicum Sjöstedt, 1918 & P7 & Garcia-Junior et al. 2020 \\
\hline Acanthagrion apicale Selys, $1876^{*}$ & P2 & \\
\hline Acanthagrion egleri (Santos, 1961) & P2, P10 & Garcia-Junior et al. 2020 \\
\hline Acanthagrion kennedii Williamson, 1916 & P1, P2, P8, P10, P15 & Garcia-Junior et al. 2020 \\
\hline Acanthagrion phallicorne Leonard, $1977^{*}$ & P5 & \\
\hline Acanthagrion truncatum Selys, $1876^{*}$ & P4 & \\
\hline Aceratobasis macilentum (Rambur, 1842) & P1, P7, P8, P10 & Garcia-Junior et al. 2020 \\
\hline \multicolumn{3}{|l|}{ Aeolagrion dorsale (Burmeister, 1839)* } \\
\hline Argia fumigata Hagen in Selys, 1865 & $\mathrm{P} 1, \mathrm{P} 14, \mathrm{P} 15$ & Garcia-Junior et al. 2020 \\
\hline Argia gemella Garrison \& von Ellenrieder $2015^{*}$ & P1 & \\
\hline Argia indicatrix Calvert, $1902^{*}$ & P1 & \\
\hline Argia oculata Hagen in Selys, $1865^{*}$ & P1 & \\
\hline Argia pulla Hagen in Selys, $1865^{\star}$ & P4 & \\
\hline Argia translata Hagen in Selys, $1865^{*}$ & P4 & \\
\hline \multicolumn{2}{|l|}{ Epipleoneura capilliformis (Selys, 1886) } & Pessacq, 2014 \\
\hline Epipleoneura new sp. & P1 & \\
\hline \multirow{2}{*}{\multicolumn{3}{|c|}{ Epipleoneura pereirai Machado, 1964}} \\
\hline & & \\
\hline Homeoura nepos (Selys, 1876) & P8, P10 & \\
\hline Inpabasis rosea (Selys, 1877) & P2, P14, P15 & Garcia-Junior et al. 2020 \\
\hline Ischnura capreolus (Hagen, 1861) & $\mathrm{P} 1, \mathrm{P} 7, \mathrm{P} 13, \mathrm{P} 16$ & Heckman, 2008; Garcia-Junior et al. 2020 \\
\hline Ischnura fluviatilis Selys, 1876 & P1, P2, P10, P12, P16 & Heckman, 2008; Garcia-Junior et al. 2020 \\
\hline \multicolumn{3}{|l|}{ Leptagrion aculeatum Santos, 1965} \\
\hline Nehalennia minuta (Selys in Sagra, 1857)* & P10 & \\
\hline Neoneura bilinearis Selys, 1860 & P5, P6, P11 & \\
\hline Neoneura gaida Rácenis, 1953* & P1 & \\
\hline \multicolumn{2}{|l|}{ Neoneura joana Williamson, 1917} & Lencioni, 2005; Heckman, 2008 \\
\hline Neoneura myrthea Williamson, 1917 & $\mathrm{P} 1, \mathrm{P} 6$ & Pessacq et al. 2012 \\
\hline Neoneura rubriventris Selys, $1860^{*}$ & P5, P6 & \\
\hline \multicolumn{2}{|l|}{ Neoneura schreiberi Machado, 1975} & Lencioni, 2005; Heckman, 2008 \\
\hline Neoneura sylvatica Hagen in Selys, $1886^{*}$ & P4 & \\
\hline Mecistogaster linearis (Fabricius, 1777)* & P1, P7 & \\
\hline \multirow{2}{*}{\multicolumn{3}{|c|}{$\begin{array}{l}\text { Mecistogaster lucretia (Drury, 1773) } \\
\text { Metaleptobasis manicaria Williamson, 1915* }\end{array}$}} \\
\hline & P1, P5 & \\
\hline \multicolumn{3}{|l|}{$\begin{array}{l}\text { Microstigma rotundatum Selys, } 1860^{*} \\
\text { Microstigma maculatum Hagen in Selys, } 1860^{*}\end{array}$} \\
\hline \multirow{2}{*}{\multicolumn{3}{|c|}{$\begin{array}{l}\text { Microstigma maculatum Hagen in Selys, } 1860^{*} \\
\text { Phasmoneura exigua (Selys, } 1886 \text { ) }\end{array}$}} \\
\hline & P1, P6, P14, P15 & Garcia-Junior et al. 2020 \\
\hline Phoenicagrion flammeum (Selys, 1876) & P10 & Lencioni, 2006; Heckman, 2008 \\
\hline \multicolumn{3}{|l|}{ Phoenicagrion flavescens Machado, 2010} \\
\hline Protoneura scintilla Gloyd, 1939* & P5 & \\
\hline Psaironeura tenuissima Selys, $1886^{*}$ & $\mathrm{P} 1, \mathrm{P} 12$ & \\
\hline Telebasis carminita Calvert, 1909 & P10 & \\
\hline Telebasis griffinii (Martins, 1896) & P8 & Garcia-Junior et al. 2020 \\
\hline \multicolumn{3}{|l|}{ Dicteriadidae } \\
\hline Heliocharis amazona Selys, 1853 & P12 & Garcia-Junior et al. 2020 \\
\hline \multicolumn{3}{|l|}{ Heteragrionidae } \\
\hline Heteragrion ictericum Williamson, 1919 & $\mathrm{P} 1, \mathrm{P} 12, \mathrm{P} 13$ & Garcia Junior et al. 2020 \\
\hline Hetaragrion macilentum Hagen in Selys, $1862^{*}$ & P1 & \\
\hline Oxystigma petiolatum (Selys, 1862) & P1, P14, P16 & Garcia-Junior et al. 2020 \\
\hline \multicolumn{3}{|l|}{ Perilestidae } \\
\hline Perilestes gracillimus Kennedy, 1941 & P1 & \\
\hline Perissolestes cornutus (Selys, 1886)* & P1 & \\
\hline
\end{tabular}

\section{Platystictidae}

Palaemnema brasiliensis Machado, 2009

Polythoridae

Chalcopteryx seabrai Santos \& Machado, 1961

Machado, 2009

Tabla 1. Lista de especies registradas para el estado de Amapá. Ubicación de los puntos de recolección presentes en la tabla 1. * Nuevos registros para el estado.

Table 1. List of species registered for the state of Amapá. Location of the collection points present in figure 1. * New records for the State. 


\section{Discussion}

The suborder Zygoptera in Brazil comprises approximately 400 species (Pinto 2018). According to the De Marco \& Vianna (2005) the largest amount of information about the order Odonata is concentrated mainly in the states Southeast region. For the southeastern of the country the suborder Zygoptera comprises 159 species (Lencioni 2017). In Brazil, several works with dragonflies have been developed lately: Rodrigues \& Roque (2017), Rodrigues et al. 2018 in Mato Grosso do Sul, Dalzochio et al. (2018), Pires et al. 2019 in the state of Rio Grande do Sul and Koroiva et al. (2020a, 2020b) in Amazonas. Among the Odonata that were identified in these works 87, 62 and 146 were species of Zygoptera respectively, greater diversities than the one found in the state of Amapá today. Garcia-Junior et al. 2020 reported the presence of 23 species of Zygoptera for the Amapá. The results presented during the present study increase the number of damselflies occurrences in the state by approximately $44 \%$, however, the sampling effort employed is still very low; probably the diversity of zygopterans in Amapá is relatively much greater than the 58 species recorded until the moment.

The collector curves did not stabilize, suggesting that sampling effort was not sufficient to register a representative number the species of dragonflies of the state (Fig. 2).

With 45 species, the Coenagrionidae family was the most representative during the present study. Similar results were also found by (Costa $e t$ al. 2000, Nóbrega \& De Marco 2011, Rodrigues

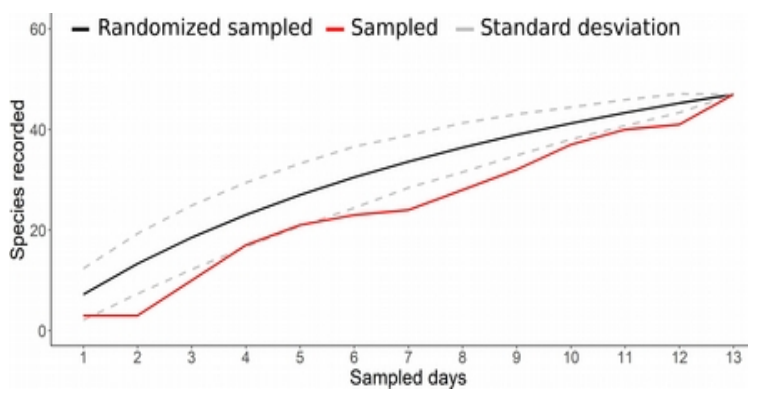

Figura 2. Curva de rarefacción y su intervalo de confianza $(95 \%$ CI) de las especies de Zygoptera recolectadas en los condados de Laranjal do Jari, Macapá, Mazagão Velho, Oiapoque y Porto Grande (AP), Brasil.

Figure 2. Rarefaction curve and its confidence interval $(95 \% \mathrm{CI})$ of Zygoptera species collected in the counties of Laranjal do Jari, Macapá, Mazagão Velho, Oiapoque and Porto Grande (AP), Brazil.
\& Roque 2017, Rodrigues et al. 2018, Dalzochio et al. 2018, Koroiva et al. 2017, 2020a). In Brazil, Coenagrionidae is the family with the greatest diversity of genera and species (Pinto 2018), which increases the possibility of being the most representative group of Zygopterans in fauna surveys. A new species of Coenagrionidae belonging to the genus Epipleoneura Williamson, 1915 was collected in the municipality of Laranjal do Jari in an area of lotic environment and it is in process of description.

Some species of Coenagrionidae showed wide distribution among the sampling points; $A$. kennedii and Ischnura fluviatilis Selys, 1876, for example, were collected in five different locations. The greater diversity of the family makes it possible for some of its species to have greater plasticity, reducing the specificities of micro-habitat common among Zygoptera. In addition, Coenagrionidae species may be responding better to factors that limit the distribution and occupation of zygopterans in the environment, such as: adaptation to environmental variables (Juen \& De Marco 2011), resource sharing (De Marco \& Resende 2004), ecophysiological conditions (Corbet 1999), the reduction of environmental integrity (Pinto et al. 2012, Carvalho et al. 2013, Monteiro-Junior et al. 2013, 2014, Brasil et al. 2014).

Among the new records (Fig. 3) for the state, some of the species have greatly expanded their range of distribution in the country, Argia translata Hagen in Selys, 1865, which occurrence was registered before only for the state of Amazonas (Koroiva et al. 2020a), expanded its distribution by approximately $900 \mathrm{~km}$. Heteragrion cinnamomeum Selys, 1862 is recorded for the first time in the Amazon region, according to Lencioni (2017) the species in Brazil occurs in the Southeast (Rio de Janeiro) and Northeast (Bahia).

According to De Marco \& Vianna 2005 the area of the Guiana Shield, where the state of Amapá is located, is extremely lacking studies with the order Odonata. Therefore, this work is of great importance in recognizing the diversity of the order, not only in the state but also in the Amazon biome. There is also a need to seek more information about the region's odonatofauna, and greater sampling in different areas should further increase the number of species occurrences for the state. 


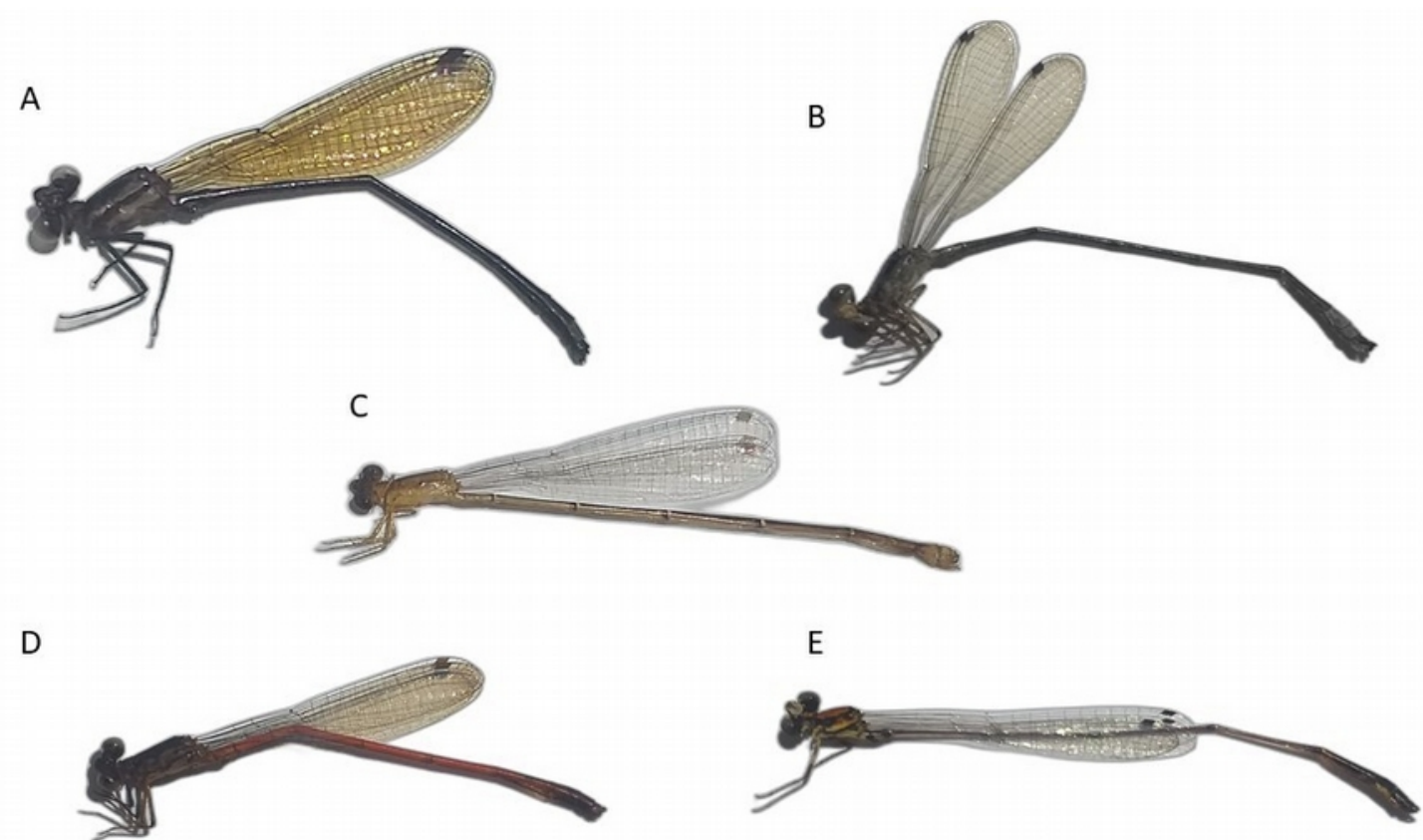

Figura 3. Especies de Zygoptera con nuevos registros para el estado de Amapá: Coenagrionidae, Coenagrionidae, A: Argia gemella Garrison \& von Ellenrieder, 2015; Coenagrionidae, B: Aeolagrion dorsale (Burmeister, 1839); Coenagrionidae, C: Metaleptobasis manicaria Williamson 1915; Coenagrionidae, D: Neoneura rubriventris Selys, 1860 e Coenagrionidae, E: Protoneura scintilla Gloyd, 1939.

Figure 3. Species of Zygoptera with new records for the state of Amapá: Coenagrionidae, Coenagrionidae, A: Argia gemella Garrison \& von Ellenrieder, 2015; Coenagrionidae, B: Aeolagrion dorsale (Burmeister, 1839); Coenagrionidae, C: Metaleptobasis manicaria Williamson 1915; Coenagrionidae, D: Neoneura rubriventris Selys, 1860 and Coenagrionidae, E: Protoneura scintilla Gloyd, 1939.

\section{Acknowledgments}

This study was partially supported by CAPES (Coordenação de Aperfeiçoamento de Pessoal de Nível Superior) and FAPEAP (Fundação de Amparo a Pesquisa do Estado do Amapá).

\section{References}

Brasil LS, Batista JD, Giehl NFS, Valadão MBX, Santos JS \& Silva KD. 2014. Environmental integrity and damselfly species composition in Amazonian streams at the "arc of deforestation" region, Mato Grosso, Brazil. Acta Limnologica Brasiliensia 26: 3. https://doi.org/10.1590/S2179975X2014000300007

Carvalho FG, Oliveira-Junior JMB, Faria APJ \& Juen L. 2013. Uso da curva abc como método para detectar o efeito de modificação antropogênica sobre assembleia de Odonata (insecta). Interciencia 38(7): 516- 522.

Clausnitzer V, Kalkman VJ, Ramc M, Collen B, Baillie JEM, Bedjanic M, . . W Wilson K. 2009. Odonata enter the biodiversity crisis debate: the first global assessment of an insect group. Biological Conservation 142(8): 1864-1869. https://doi.org/10.1016/j. biocon.2009.03.028

Corbet PS. 1980. A biology of Odonata. Annual Review of Entomology 25: 189-217.

Corbet PS. 1999. Dragonflies: behavior and ecology of Odonata. Comstock Publ. Assoc. Ithaca, NY.
Costa JM, Santos TC \& Oldrini BB. 2012. Odonata Fabricius, 1792. pp. 245-256. In: Rafael JA, Melo GAR, Carvalho CJB, Casari AS, Constantino R. Insetos do Brasil. Diversidade e Taxonomia. Ribeirão Preto: Holos Editora.

Costa JM, Machado ABM, Lencioni FAA \& Santos T. C. 2000. Diversidade e distribuição dos Odonata (Insecta) no estado de São Paulo, Brasil. Publicações Avulsas do Museu Nacional 80(1): 1-27.

Dalzochio MS, Renner S, Sganzerla C, Prass G, Ely GJ, Salvi LC, . . Périco E. 2018. Checklist of Odonata (Insecta) in the state of Rio Grande do Sul, Brazil with seven new records. Biota Neotropica 8: 4. http://dx.doi.org/10.1590/1676-0611-bn-2018-05 51

De Marco PJR \& Resende DC. 2004. Cues for Territory Choice in Two Tropical Dragonflies. Neotropical Entomology 33: 397-401. http://dx.doi.org/10.1590/S1 519-566 X2004000400001.

De Marco PJR \& Vianna DM. 2005. Distribuição do esforço de coleta de Odonata no Brasil subsídios para escolha de áreas prioritárias para levantamentos faunísticos. Lundiana 6:13-26.

De Marco PJR, Juen L, Batista JD, Furieri KS \& Neiss U. G. 2018. Livro Vermelho da Fauna Brasileira Ameaçada de Extinção: Volume VII. (Invertebrados Odonata). Brasilia: ICMBio/MMA.

Dijkstra KDB, Bechly G, Bybee SM, Dow RA, Dumont HJ, Fleck G, ... Ware J. 2013. The classification and diversity of dragonflies and damselflies (Odonata). In: Zhang Z.-Q. (Ed.), Animal biodiversity: An outline of higher-level classification and survey of taxonomic richness (Addenda 2013). Zootaxa 3703: 36-45. https://doi.org/10.11646/zootaxa. 
$\underline{3703.1 .9}$

Garcia-Junior MDN, Damasceno MTS, Martins MJL, Costa TS, Ferreira RMA \& Souto RNP. 2020. New records of dragonflies and damselflies (Insecta: Odonata) from Amapá state, Brazil. Biota Neotropica 21(1): e20201074. https://doi.org/10.1590/1676-06 11-BN-2020-1074

Garrison RW, Von Ellenrieder N \& Louton JA. 2010. Damselfly Genera of The New World: an illustrated and annotated key to the Zygoptera. Baltimore: The John Hopkins University Press.

Heckman CW. 2006. Encyclopedia of South American aquatic insects: Odonata - Anisoptera. Netherlands: Springer.

Juen L \& De Marco PJR. 2011. Odonate biodiversity in terra-firme forest streams in Central Amazonia: on the relative effects of neutral and niche drivers at small geographical extents. Insect Conservation and Diversity 4: 265-274. https://doi.org/10.1111/j.17524598.2010.00130.x

Kalkman VJ, Clausnitzer V, Dijksta KDB, Paulson R \& Vantol J. 2008. Global diversity of dragonflies (Odonata) in freshwater. Hydrobiologia 595: 351363. https://doi.org/10.1007/s10750-007-9029-x

Koroiva R, Rodrigues ME, Valente-Neto F \& Roque F. de O. 2017. Odonates from Bodoquena Plateau: checklist and information about endangered species. Biota Neotropica 17(3):e20160310. https://doi.org/ 10.1590/1676-0611-bn-2016-0310

Koroiva R, Neiss UG, Fleck G \& Hamada N. 2020a. Checklist of dragonflies and damselflies (Insecta: Odonata) of the Amazonas state, Brazil. Biota Neotropica 20(1). https://doi.org/10.1590/1676-0611-bn2019- 0877

Koroiva R, Brasil PG, Neiss UG, Vilela DS \& Hamada. 2020b. Dragonflies and damselflies (Insecta: Odonata) housed in the Invertebrate Collection of the Instituto Nacional de Pesquisas da Amazônia, Brazil. Hetaerina 2(2): 14-23.

Lencioni FAA. 2005. The Damselflies of Brazil: An Illustrated Identification Guide 1 - The Non coenagrionidae families. São Paulo: All Print Editora.

Lencioni FAA. 2006. The Damselflies of Brazil: An Illustrated Identification Guide 2 - Coenagrionidae. São Paulo: All Print Editora.

Lencioni FAA. 2017. Damselflies of Brazil - an illustrated identification guide -Southeast region. Editión of autor available in https://zygopterabiobr.files. wordpress.com/2017/10/damselflies_of_brazil_south east site1.pdf

Machado ABM. 2009. Palaemnema brasiliensis spec. nov., first Platystictidae record from Brazil (Zygoptera). Odonatologica 38(3): 255-260.

Machado ABM. 2010. Four new species of Phoenicagrion von Ellenrieder, 2008 from Brazil (Odonata, Coenagrionidae). Zootaxa 2517: 44-52. https://doi. org/ 10.11646/zootaxa.2517.1.5

Mcpeek MA. 1989. Diferential dispersal tendencies among Enallagma damselfies inhabiting diferent habitats (Odonata). Oikos 56: 187-195. https://doi. org/10.2307/3565335

Monteiro-Júnior CS, Couceiro SRM, Hamada N \& Juen
L. 2013. Effect of vegetation removal for road building on richness and composition of Odonata communities in Amazonia, Brazil. International Journal of Odonatology 16(2): 135-144. http://dx.doi.org/10. 1080/13887890.2013.764798

Monteiro-Júnior CS, Juen L \& Hamada N. 2014. Effects of urbanization on stream habitats and associated adult dragonfly and damselfly communities in central Brazilian Amazonia. Landscape and Urban Planning 127: 28-40. http://dx.doi.org/10.1016/j.landurb plan.2014.03.006

Nóbrega CC \& De Marco PJR. 2011. Unprotecting the rare species: a niche-based gap analysis for odonates in a core Cerrado área. Diversity and Distributions 17(3): 491-505. https://doi.org/10.1111/j. 1472- 4642.2011.00749.x

Oksanen J, Blanchet FG, Friendly M, Kindt R, Legendre P, Mcglinn D, . . . Wagner H. 2019. vegan: Community Ecology Package. $\mathrm{R}$ package version 2.5-5. https://CRAN.R-project.org/ package=vegan

Oliveira MJ. 2010. Diagnóstico do setor mineral do Estado do Amapá. Macapá: Instituto de Pesquisas Cientificas e Tecnológicas do Estado do Amapá.

Pessacq P, Chrysostomo TS \& Costa JM. 2012. Checklist and updated distribution of Protoneuridae from Brazil, International Journal of Odonatology 15(2): 59-73., https://doi.org/10.1080/13887890.2012.6721 $\underline{58}$

Pessacq P. 2014. Synopsis of Epipleoneura (Zygoptera, Coenagrionidae, "Protoneuridae"), with emphasis on its Brazilian species. Zootaxa 3872(3): 201-234. http://dx.doi.org/10.11646/zootaxa.3872.3.1

Pinto NS, Juen L, Cabette HSR \& De Marco PJR. 2012. Fluctuating assymmetry and wing size of Argia tinctipennis Selys (Zygoptera: Coenagrionidae) in relation to riparian forest preservation status. Neotropical Entomology 41(3): 178-185. http://dx.doi.org/10. 1007/s13744-012-0029-9

Pinto AP. 2018. Odonata in Catálogo Taxonômico da Fauna do Brasil. PNUD. http://fauna.jbri.gov.br/ fauna/faunadobrasil/171 [Accessed 16 December 2020].

Pires MM, Kotzian CB, Dalzochio MS, Sganzerla C, Prass G \& Périco E. 2019. Diversity of Odonata (Insecta) in Seasonal Deciduous Forest fragments in southern Brazil (state of Rio Grande do Sul), with a new record for the state and comments on the seasonal distribution of the species. Biota Neotropica 19(4): e20190769. http://dx.doi.org/10.1590/16760611-BN-2019-0769

R Core Team. 2019. R: A language and environment for statistical computing. R Foundation for Statistical Computing, Vienna, Austria. https://www.Rproject.org/

Rodrigues ME \& Roque FO. 2017. Checklist de Odonata do Estado de Mato Grosso do Sul, Brasil. Iheringia Série Zoologia 107(supl.): e2017117. http://dx.doi.org/10.1590/ 1678-4766e2017117

Rodrigues ME, Moura EB, Koroiva R, Borges ACP \& Roque FO. 2018. Survey of Dragonflies (Odonata) in Palm Swamps of Cerrado Hotspot. Entomological News 128(1): 24-38. http://dx.doi.org/10.3157/021. 128.0104 
Santos ND \& Machado ABM. 1961. Contribuição ao conhecimento do gênero Chalcopteryx Selys, 1853, com a descrição de uma nova espécie. Boletim do Museu Paraense Emílio Goeldi 24: 1-15.

Silveira OT. 2003. Fauna de Insetos das Ressacas das Bacias do Igarapé da Fortaleza e do Rio Curiaú. In Diagnóstico das Ressacas do Estado do Amapá: Bacias do Igarapé da Fortaleza e Rio Curiaú
(Takiyama, L.R. \& Silva A.Q. da, orgs.). Macapá, AP, CPAQ/IEPA e DGEO/SEMA, 73-80.

Trueman JWH. 2007. A brief history of the classification and nomenclature of Odonata. Zootaxa 1668: 381394. https://doi.org/10.11646/zootaxa.1668.1.20

Von Ellenrieder N. 2009. Databasing dragonflies: state of knowledge in the Neotropical region. Agrion 13: 58- 72. 